\title{
Interlingua Interferences in English and Russian in Physics Field
}

\section{Interferencias interlingua en inglés y ruso en el campo de la física}

\author{
Khanif Fakhretdinovich Makayev \\ Associate Professor of the Department of Foreign Languages of the Institute of International \\ Relations of Kazan Federal University \\ ORCID ID: https://orcid.org/0000-0001-6953-2329
}

\section{Marat Aidarovich Yahin}

Senior Lecturer of the Department of Foreign Languages of the Institute of International Relations of Kazan Federal University

ORCID ID: https://orcid.org/0000-0003-4383-5086

\section{Guzal Zainagiyevna Makayeva}

Associate Professor of the Department of Foreign Languages of the Institute of Kazan State

University of Structure and Engineering

ORCID ID: https://orcid.org/0000-0002-8656-328X

Received 09-08-20 Revised 10-10-20 Accepted 20-12-21 On line 02-20-21

* Correspondence

Email: yakhinmarat94@gmail.com
Citation:

Khanif Fakhretdinovich Makayev, Marat Aidarovich Yahin, Guza Zainagiyevna Makayeva (2021) Interlingua Interferences in English and Russian in Physics Field. Propósitos y Representaciones, 9(SPE2), e1019. http://dx.doi.org/10.20511/pyr2021.v9nSPE2.1019 


\section{Summary}

Proper knowledge of a language requires being aware of such interlingua interference as "false friends of a translator". The research conducted with higher school students revealed the fact of misunderstanding and their being confused when dealing with the stratum of terminology under consideration. Therefore, the aim of the paper is to consider 'false friends of a translator' in physics field taking account of their similarities or differences in the pronunciation, meaning and spelling in English and Russian. For realizing this aim the authors empirically surveyed two groups of higher school final-year students to contribute to their language development through good knowledge of terms. The research was conducted on the base of comparison, observation and empirical methods and the teaching-practicing-controlling approach. The results obtained show that proper educating the future specialists to the use of the lexical units under consideration correctly can improve their language knowledge for their professional growth. The results can be used in language teaching practice, in making dictionaries for special purposes, as well as for making some possible contribution to terminology science.

Keywords: language, communication, student, 'false friends of a translator', terminology, education.

\section{Resumen}

El conocimiento adecuado de un idioma requiere ser consciente de interferencias interlingüísticas como "falsos amigos de un traductor". La investigación realizada con estudiantes de educación superior reveló el hecho de malentendidos y confusión al tratar con el estrato de terminología considerado. Por tanto, el objetivo del trabajo es considerar a los "falsos amigos de un traductor" en el campo de la física teniendo en cuenta sus similitudes o diferencias en la pronunciación, el significado y la ortografía en inglés y ruso. Para lograr este objetivo, los autores encuestaron empíricamente a dos grupos de estudiantes de último año de la escuela superior para contribuir a su desarrollo del lenguaje mediante un buen conocimiento de los términos. La investigación se llevó a cabo sobre la base de métodos de comparación, observación y empíricos y el enfoque enseñanza-práctica-control. Los resultados obtenidos muestran que una adecuada educación de los futuros especialistas en el uso correcto de las unidades léxicas consideradas puede mejorar sus conocimientos lingüísticos para su crecimiento profesional. Los resultados se pueden utilizar en la práctica de la enseñanza de idiomas, en la elaboración de diccionarios para fines especiales, así como para hacer alguna posible contribución a la ciencia de la terminología.

Palabras clave: idioma, comunicación, estudiante, "falsos amigos de un traductor", terminología, educación.

\section{Introduction}

The effective use of English by specialists means understanding the speech properly and extracting useful information from it for advancing in the carrier and sounding correctly during the professional activity. This goal can often be hampered by the so-called interlingua interference, which refers to the erroneous identifying of the elements or structures of one language with the elements or structures of another. We are talking about the interlingua homonyms known as "false friends of a translator" in physics field. This phenomenon caused the interest of researchers at the end of the 19th century. The concept was examined in 1928 by the French lexicographers M. Koessler and J. Derocquigny on the basis of French-English and English-French parallels, where only the sound similarity of the words of two languages was considered (Koessler \& Derocquigny, 1928). In Russia the term under consideration appeared in the late 60 s - early 70 s of the twentieth century under different terminological designations. The process of terms managing can get complicated because of the existence of words completely similar in pronunciation and spelling in the target and the origin languages, but different in the meaning and words with identical pronunciations but different spellings and meanings. This paper considers also partially mismatched terms and the terms which have several meanings. When dealing with the 'false friends of a translator' one may come across a lot of misunderstandings because of the fact that 
many English words are homonymous with the Russian ones. So, the aim of the study is to explore lexical units of physics field from the point of view of their similarities and differences in their phonetic, orthographic, semantic features considering their belongings to parts of speech, meanings and structure. In linguistics they are usually defined as homonyms, paronyms, homophones, heteronyms, capitonyms, and oronyms. The necessity and actuality of this research are underlined by such scientists as (Sabino, 2011b; Grossman, 2010). "False friends of a translator" as an interlanguage phenomenon was studied by (Belyayeva, 2014; Inkova, 1992; Pivovarova, 2013; Makayev et al., 2019). The issue of the relationships of language proficiency, communication patterns, and safety performance was considered by such researchers as (Bavelas, 1950). The physics lexical units that represent "false friends of a translator" were not completely analyzed linguistically from the point of view of their ability of causing some confusion for specialists in the process of their use. The main methods the research was based on are the comparison, observation and empirical methods and the teaching-practicing-controlling approach. The research conducted showed that the terms in both languages have similarities and differences which may cause confusion during the interpretation process (Baklashova \& Abdullina, 2018). The study proves that when choosing an appropriate interpretation option from several ones it is necessary to take into account the general meaning of all the material being interpreted, its part, sentence or part of the utterance. To comprehend the material it is necessary also to use dictionaries for the correct meanings of the terms being comprehended.

\section{Methods}

The research is based on the scientific works of such scientists as Borisova L.I., Comissarov V.N., Akulenko V.V., Basmanova A.G., Comissarchic S.Yu., Pogorelova R.V., Grossman E., Baker M., Bell R.T., Robinson D. and others. For conducting the research the survey's results, made among higher school students, and two physics groups' students were used. The main methods the research is based on are the comparison, observation and empirical methods and the teachingpracticing-controlling approach. Essential information was got from contacting with the specialists of physics field. The comparison method ensures taking into account the similarities and differences between terms of the languages under consideration in their phonetic, orthographic, semantic features. Through the observation method we analyzed literature, as well as dictionaries, and find out the similarities and differences of the meanings of the terms in the languages under consideration.

\section{Results and Discussion}

The existence of the international vocabulary and borrowings can be misleading. An effective way for a specialist to cope with them is to learn, know and practice. One of the ways of teaching these terms to the language learners is training them in hypothetical professional situations. The research showed that proper knowledge of the lexical units allows the students to manage with the hypothetical professional problematic situations connected with the use of 'false friends of a translator.' While conducting the teaching-practicing-controlling process we observed increased compliance with confusion and misunderstanding facts hypothetically.

\section{Complete mismatch values}

These are the English words completely similar to the Russian ones in spelling and sounding, but different in meaning: 'clay' (noun) - 'глина, not 'клей, приклеивать - glue'; 'accurate' (adjective) - 'точный', not 'аккуратный - neat, tidy, orderly'; 'lift' (verb) - 'поднимать', not 'лифт - elevator'; 'commutator' (noun) - 'эл. переключатель', not 'телефонный коммутатор telephone switchboard, telephone switch'; 'electric' (adjective) - 'электрический', not 'электрик - electrician'; 'focus' (noun) - 'оптический фокус', not 'трюк фокусника - magician's trick'. On the whole, these terms refer to nouns, though some adjectives also can be found among them. The reason of incorrect interpretation of such terms is in an inappropriate way of rendering of international words. It should be noted that not only sounding and spelling of some terms coincide in the target and the origin languages, but their meanings as well (atom, element). 
From the linguistic point of view these terms are called homonyms, i.e. words with identical spelling and pronunciation but different meanings. They also are called homographs. Another group of false friends of a translator are paronyms, i.e. words with almost complete similarities in pronunciation but different spelling and meaning (accept - verb - to take or receive what is offered; except - preposition - excluding; collision - noun - crash, clash, conflict; collusion - noun - a secret agreement that is oftentimes illegal). As it can be seen from the examples, the terms belong to different parts of speech, particularly to main parts of speech (nouns, verbs) and the official parts of speech (preposition). Paronyms are also called homophones that mean words with identical pronunciations but different spellings and meanings too (to preposition; too - adverb - also; two - determiner - numeral 2). Besides, among the terms there can be found the words with identical spellings but different meanings. They are called homographs which may have both identical and different pronunciation as well (wind [wind] -

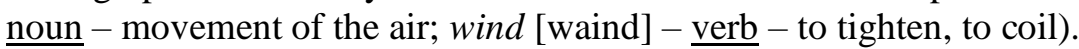

While dealing with these terms it is important to clarify what part of speech they represent. Specialists should also pay attention to the terms containing differences only in one or two letters which can distort the whole meaning of the information interpreted (collision - collusion; acceptexcept). Among 'false friends of a translator' there could be those used as a term in English and become obsolete in the Russian language: 'invalid' - 'несостоятельный', 'непригодный' (adjective). In the Russian language the term 'invalid' means a disabled person (noun). The term is used in different main parts of speech: a noun and an adjective. While using it attention should be given to this factor to avoid possible errors. Choice of the appropriate meaning is the matter of paying great attention to when working with such terms. It is better to remember such words, since mistakes are inevitable.

Great help with "false friends of a translator" is usually provided by special dictionaries of false translator friends, for example, edited by V.V. Akulenko. Thus, when dealing with the terms with complete mismatch values from English into Russian and vice versa specialists should divide the text into parts for relating the term under consideration to one of them. The sentence or part of the utterance is to be analyzed for defining the proper meaning of the term. The meaning of the term could be defined due to the current situation as well. Even if the information comprehended is more or less acceptable, the worker should double check the meaning of the term by dictionaries or more experienced colleges.

\section{Partial mismatch values}

Partial mismatching among physics terms occur usually in word combinations when one component of the origin language word combination is completely similar to the corresponding word in the target language, but its meaning is different (effective inductance - кажущзаяся индуктивность). 'Effective' means 'эффективный' (striking, showy) but in the expression 'effective inductance' 'кажущаяся' is translated as 'apparent'. The translation of such terms should be dealt, if necessary, with specialists of the field the term belongs to. Only specialists are able to cope with the right way of interpreting this or that term of the professional fields, physics fields as well. Such words are considered to be narrow specialism terms, the interpretation of which is usually under the competence of professionals only.

The terms having differences in one-two letters in both origin and target languages also can be classified as those to which peculiar is a partial mismatch value. Among the terms in the languages considered there are found words similar in spelling to the words of common use (currant - смородина и current - ток, поток, сотрlement - дополнение, комплект и compliment - похвала). While dealing with "false friends of a translator" one can get confused dealing with word combinations, one component of which is a complete mismatch in both the origin and target language in meaning, spelling and pronunciation. Such word combinations can be related to terms of partial mismatch values.

The most comprehension difficulties may occur with the second component of the word combination. We are talking about collocations of the word, for example, accurate which should 
be treated as set phrases (accurate description, accurate information, accurate translation, accurate timing, and accurate watch). As for the Russian false version of the word accurate, it can be combined only with definite Russian words (аккуратный работник, аккуратная комната, аккуратный почерк, аккуратный человек). This state of affairs obliges specialists to take into consideration indestructibility of set word combinations in languages as they may cause considerable difficulties and errors. The same phenomenon should be paid attention to when dealing with the term "general" (general idea, general usage, and general terms). In the Russian language the word "генеральныи" is collocated to "генеральный директор, генеральная репетииия, генеральная уборка'.

Examples can be multiplied. So, not to distort the content of the original option one shouldn't transfer the usual meaning of a native word to the foreign word which has another meaning.

\section{The words used in several meanings}

One of the most difficult issues related to interpreting "false friends of a translator" is connected with words used in several meanings. The problem is in the right choice of the necessary option from two or more meanings (current -1 . ток-electricity; 2. настоящии - present / $\underline{\text { resin }}-1$. резина - rubber; 2. смола - resin). A specialist may also come across the words which in the plural usually have another meaning (compass - компас; compasses - ииркуль; difference различие; differences - разногласия - dissensions / development -pазвитие; developments события, обстоятельства - events, circumstances / security - безопасность; securities ценные бумаги - securities). Attention should be paid to the words with identical spellings but both different and identical pronunciations and only different meanings that are heteronyms. Many heteronyms have similar or related origins or meanings. Heteronyms are also homographs. These terms usually belong to different parts of speech ( $\underline{\text { hurt }}$ - повреждение, вред - noun; повреждать, причинять вред - verb; place - место, положение - nоип; помещать, ставить, размешчать - $\underline{\text { verb }})$.

Another group of words with identical spellings except for a difference in the capitalization but different meanings are capitonyms. Capitonyms may have identical or different pronunciations. For example: mercury - $\underline{\text { noun }}$ - a chemical element; Mercury - $\underline{\text { noun }}$ - a planet. Among paronymic phrases there may be found oronyms, phrases with similar pronunciations but different spellings and meanings (four candles - fork handles). There can be found terms used in several meanings among which there exist those similar to and different from Russian analogues. For example: complex

1. сложный - consisting of many details and difficult to understand;

2. комплекс - an emotional problem, when someone worries about something, usually without a real reason;

3. группа - a group of things.

So, paronyms, homophones, homographs, homonyms, heteronyms, capitonyms, and oronyms are to be studied thoroughly in languages. Previous investigations have resulted in publication of such dictionaries as

1. 'English-Russian and Russian-English dictionary of "the false friends of a translator" by Akulenco V.V.';

2. "German-Russian and Russian-German dictionary of "the false friends of a translator" by Gotlib K.G.';

3. 'Russian - French dictionary compiled by Muraviev V.A.';

4. 'False friends of a translator in Czech" by Zhuravlev A.I. and Zaharov S.S.'

These dictionaries make the process of terms use much easier by helping the specialists find words similar in spelling in both origin and target languages but different in meaning. A language depicts the culture of the people speaking in it, and different people own different cultures which, in its turn, make the languages differ from each other. This fact makes workers find «equivalence» while dealing with the professional terms instead of rendering word for word 
(Bell, 1991; Robinson, 2003; Gutt, 2000; Steiner, 1998). We completely agree with W. Wilss who defines translation as «a text-oriented event. Translation is a procedure which leads from a written source language text to an optimally equivalent target language text and requires syntactic, semantic and stylistic and text - pragmatic comprehension by the translator of the original text» (Wilss, 1982).

The paper states that while dealing with the "false friends of a translator" special attention should be paid to phonological, lexical, grammatical, morphological, syntactic and semantic features (Sakaeva et al., 2019).

\section{Summary}

The terms under consideration have similarities and differences in pronunciation, spelling and meaning in the target language and the origin one that creates interpretation difficulties not only for beginners starting to learn the language, but also for experienced professionals. The research showed that while using the terms under consideration students should be able to specify their belonging to parts of speech, their phonetic, orthographic, semantic features, whether they are homonyms, paronyms, homophones, heteronyms, capitonyms, and oronyms (Sakaeva \& Khusnutdinov, 2019). This will help avoid possible confusions by comprehension process. Important is to consult not only English - Russian, Russian - English dictionaries but also English - English ones. The research found out that it is necessary to compile Russian - English, English Russian dictionaries for specific purposes in the physics field by consulting physics' teachers and other specialists of the fields considered.

\section{Conclusions}

When dealing with any professional terms in physics field the following ideas should be taken into consideration:

1. Do not rely completely on your native language where the terms coincide with the corresponding terms of the target language in pronunciation, spelling and meaning. Every term should be checked up.

2. Consult the dictionaries. Do not look up the meaning of "false friends of a translator" in the Russian - English and English - Russian dictionaries only. The best way to deal with them is to use English- English dictionaries as well.

3. Comprehension process should be conducted by dividing the text being interpreted into parts for relating the terms under consideration to one of them.

4. A physics specialist shouldn't transfer the common meaning of a native word to the foreign word which may have another meaning in the terminological field.

5. Both interpreting and compiling a dictionary processes should be conducted by cooperation with specialists of the appropriate field of physics.

6. The rational solution of the problem considered in this paper is in creating English Russian and Russian- English dictionary of construction fields' "false friends of a translator."

According to the results of the research, international vocabulary and borrowings can easily be misleading. To avoid this phenomenon it is recommended to learn and to know all these lexical units. Communicants should deal with physics texts carefully, in order to escape misunderstandings. For this, they should be able to distinguish the terms by their belonging to parts of speech, to differ them in their meaning and structure, pronunciation and spelling.

\section{Acknowledgements}

The work is performed according to the Russian Government Program of Competitive Growth of Kazan Federal University.

\section{References}

Baklashova, T.A., \& Abdullina, L.R. (2018). Text approach methodology in translators training (economic discourse) [ $\mathrm{La}$ m?thodologie d?approche du texte ?conomique dans la formation des traducteurs]. XLinguae, 11(1XL),19-32. 
Bavelas, A. (1950). Communication patterns in task orientated groups. Acoustical Society of America Journal, 22, 727-30.

Bell, R.T. (1991). Translation and translating: theory and practice (Applied Linguistics and Language Study). Addison Wesley Publishing Company, 298.

Belyayeva, V.M. (2014). "False friends of a translator" as interlanguage phenomenon. Foreign languages: linguistic and methodic aspects, 27, 133-138.

Grossman, E. (2010). Why translation matters. Yale University Press, P. 160

Gutt, E. (2000). Translation and relevance: cognition and text. Blackwell Publishers, 271.

Inkova, O.Yu. (1992). Lexical interference in the Italian and the French languages: The problem of "False friends of a translator". Dissert. ... of cand. of philol. Sciences. M. 225.

Koessler, M., \& Derocquigny, J. (1928). Les faux amis ou les trahisons du vocabulaire anglais. Conseils aux traducteurs. Paris.

Makayev, K.H., Baranova, A.R., \& Sigacheva, N.A. (2019). Ways of vocabulary enlargement in the English sublanguage of Physics. Journal of Research and Applied Linguistics, 10(SP), 793-801.

Pivovarova, Ye.V. (2013). Functioning of phrasal units "false friends of a translator" in English internet resources. Philology sciences: Issues of theory and practice, 10(28), 130-133.

Robinson, D. (2003). Becoming a translator: an introduction to the theory and practice of translation. Routledge, 320 .

Sabino, M.A. (2011b). A trajetoria das alteracoes semanticas nas linguas e os seus reflexos no campo do Ensimo de Lingua Estrangeira e da Traducao. Revista da ANPOLL (Online), 1, 193-206.

Sakaeva, L.R., \& Khusnutdinov, K.R. (2019). Peculiarities of translating terms of nanotechnology discourse. Kazan Linguistic Journal, 2(2), 54-66. (In Russ.)

Sakaeva, L.R., Yahin, M.A., Mensah, D., \& Fatkullina, F.G. (2019). The peculiarities of translations of official business plans from English into Russian [Las peculiaridades de las traducciones de planes comercialesoficiales del Ingl?s al Ruso]. Opcion, 35(23), 433-447.

Steiner, G. (1998). After Babel: Aspects of language and translation. Oxford University Press.

Wilss, W. (1982). The science of translation. Problems and methods, Gunter Narr Verlag, Tubingen. 